\title{
ANALISIS DAN PERANCANGAN SISTEM INFORMASI EVALUASI DOSEN OLEH MAHASISWA DI LINGKUNGAN UNIVERSITAS SANGGA BUANA BANDUNG
}

\author{
HANHAN HANAFIAH SOLIHIN \\ Program Studi Sistem Informasi, Universitas Sangga Buana \\ Email : hanhan.hanafiah@usbypkp.ac.id
}

\begin{abstract}
ABSTRAK
Universitas Sangga Buana telah memberlakukan Evaluasi Dosen Oleh Mahasiswa dengan menyediakan berupa kertas kuesioner yang disebar dan diisi oleh mahasiswa. Kegiatan ini dilakukan pada setiap akhir semester, yang memungkinkan data kuesioner diharapkan semua terkumpul dan dapat diolah oleh Biro Penjaminan Mutu. Kegiatan menyebarkan kuesioner ini pada prosesnya sangat banyak menggunakan kertas serta ada kemungkinan mahasiswa tidak mengisi kuesioner, dikarenakan malas atau banyak hal, pada proses pengumpulan kuesioner yang telah diisi oleh mahasiswa, lembar kuesioner dapat tercecer atau hilang dan tidak terarsip dengan baik. Pada proses penghitungan sangat memungkinkan terjadi kesalahan input data dan perhitungan oleh petugas. Kesalahan tersebut berpengaruh pada penilaian seorang dosen dinyatakan berkinerja baik atau buruk. Untuk tahapan pemodelan sistem tools yang digunakan memanfaatkan UML, selanjutnya pada penelitian ini merancang juga pemodelan user interface pada program aplikasi yang diusulkan.
\end{abstract}

Kata kunci: Evaluasi Dosen, Kuesioner, Sistem Informasi.

\begin{abstract}
Sangga Buana University has implemented Lecturer Evaluation by Students by providing information disseminated and accessed by students. This activity is carried out in each final semester, which allows data to be collected and can be processed by the Quality Assurance Bureau. Activities carried out in this process use a lot of paper, maybe students do not fill out questionnaires because of laziness or many things, in the questionnaire process that has been filled out by students, the questionnaire can be lost and not archived. right. In the calculation process, officers can make data input errors and calculations. Errors can affect when the assessment of the lecturer is declared to work well or bad. For the system modeling stage, the tools used use UML, then in this reseach also design user interface modeling in the proposed application program.
\end{abstract}

Keywords: Lecturer Evaluation, Questionnaire, Information System. 


\section{PENDAHULUAN}

Undang-Undang Nomor 14 Tahun 2005 menyatakan bahwa "Dosen adalah pendidik profesional dan ilmuwan dengan tugas utama mentransformasikan, mengembangkan, dan menyebarluaskan ilmu pengetahuan, teknologi, dan seni melalui pendidikan, penelitian, dan pengabdian kepada masyarakat.'(Republik Indonesia, 2005). Sedangkan sebuah pembelajaran yang identik dengan pendidikan menurut Undang-Undang Republik Indonesia Nomor 12 Tahun 2012 Tentang Pendidikan Tinggi menyatakan bahwa "Pembelajaran adalah proses interaksi mahasiswa dengan dosen dan sumber belajar pada suatu lingkungan belajar.'(Republik Indonesia, 2012)

Dari dua landasan ketentuan tersebut, sehingga peran dosen dan mahasiswa sangat penting bagi sebuah kegiatan belajar mengajar. Pada akhir proses kegiatan belajar mengajar, evaluasi oleh dosen tehadap mahasiswa sangat penting untuk menilai sejauh mana kemanpuan mahasiswa dalam suatu mata kuliah. Namun tidak hanya dosen saja yang dapat mengevaluasi mahasiswa, tetapi mahasiswa berhak mengevaluasi sejauh mana kinerja cara mengajar dosen atau dengan istilah yang sering disebut Evaluasi Dosen Oleh Mahasiswa (EDOM).

Universitas Sangga Buana telah memberlakukan EDOM dengan menyediakan berupa kertas kuesioner yang disebar dan diisi oleh mahasiswa. Pada prosesnya kegiatan ini dilakukan pada setiap akhir semester, yang memungkinkan data kuesioner diharapkan semua terkumpul dan dapat diolah oleh Biro Penjaminan Mutu.(Universitas Sangga Buana, 2015) Kegiatan menyebarkan kuesioner EDOM ini pada prosesnya sangat banyak menggunakan kertas untuk kuesioner serta ada kemungkinan mahasiswa tidak mengisi kuesioner dikarenakan malas atau banyak hal, selain dari itu pada proses pengumpulan kuesioner yang telah diisi oleh mahasiswa lembar kuesioner dapat saja tercecer atau hilang dan tidak terarsip dengan baik. Lalu pada proses penghitungan sangat memungkinkan terjadi kesalahan input data dan perhitungan oleh petugas. Kesalahan tersebut berpengaruh pada penilaian seorang dosen dinyatakan berkinerja baik atau buruk.

Dengan adanya Teknologi informasi yang sangat berperan pada pengolahan data menjadi sebuah informasi yang memiiki kualitas yang baik, serta keamanan yang terjaga, maka alangkah baiknya penerapan antara kuesioner EDOM yang dibantu dengan teknologi informasi dengan tujuan meminimalisir penggunaan kertas karena sudah menerapkan paperless. Selain itu mencegah adanya mahasiswa yang tidak mengisi kuesioner EDOM dan meminimalisir kesalahan perhitungan oleh petugas, selain itu dengan EDOM yang sudah menggunakan teknologi informasi dosen dapat melihat hasil dari penilaian mahasiswa melalui sebuah website.

Sehingga tujuan dari penelitian ini adalah Menganalisis dan membuat rancangan (blueprint) aplikasi Sistem Informasi untuk menunjang proses kegiatan penilaian EDOM di lingkungan Universitas Sangga Buana. 
Analisis dan Perancangan Sistem Informasi Evaluasi Dosen Oleh Mahasiswa di Lingkungan Universitas Sangga Buana Bandung

\section{PEMBAHASAN}

\subsection{Metode Penelitian}

Tahapan penelitian yang akan di gunakan dalam penyelesaian penelitian ini dapat dilihat pada gambar 1 , seperti gambar dibawah ini.

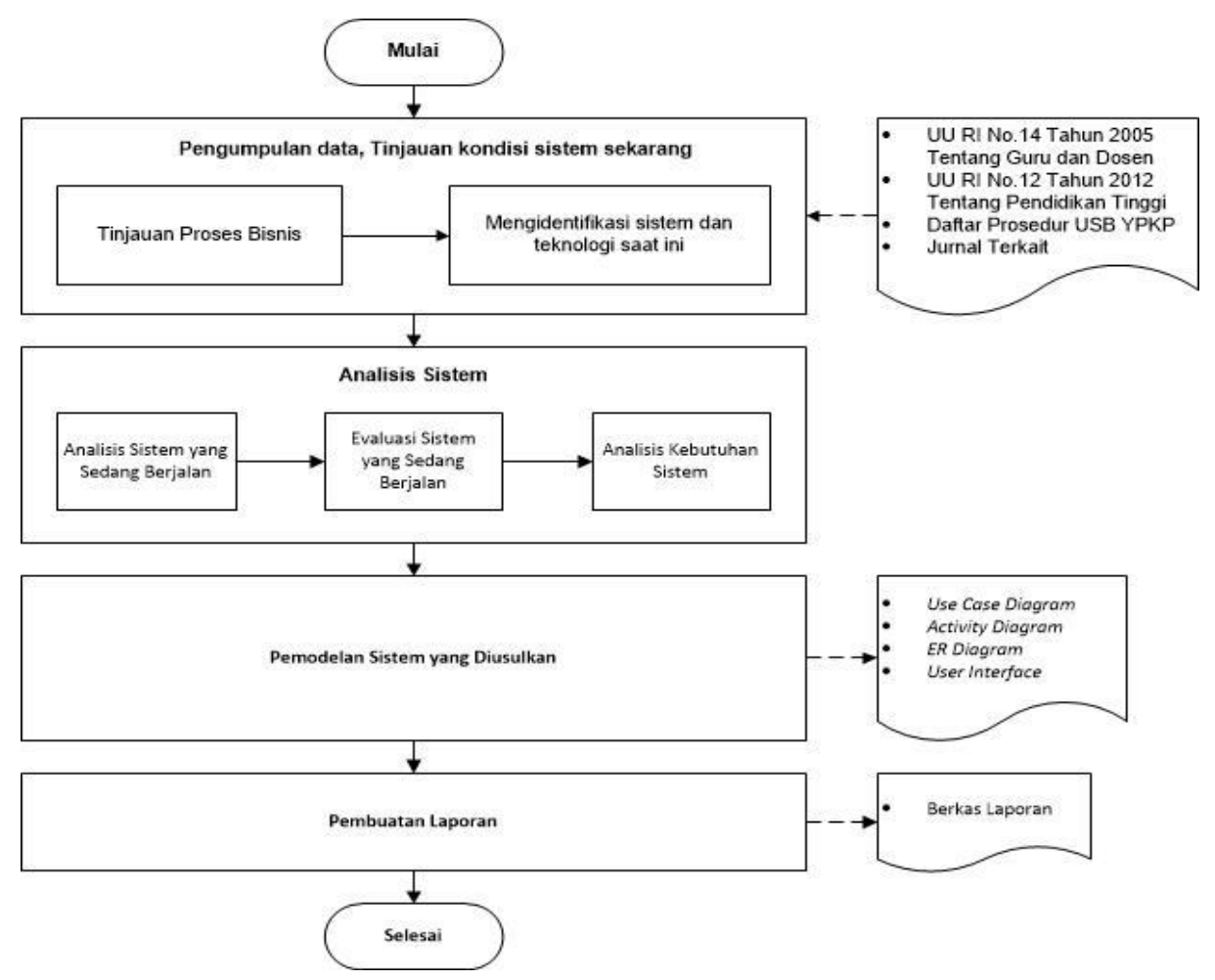

Gambar 1. Tahapan Penelitian

\subsection{Analisis Sistem Yang Sedang Berjalan}

Pada prosedur sistem EDOM yang sedang berjalan Universitas Sangga Buana telah memberlakukan EDOM dengan menyediakan berupa kertas kuesioner yang disebar dan diisi oleh mahasiswa. Pada prosesnya kegiatan ini dilakukan pada setiap akhir semester, yang memungkinkan data kuesioner diharapkan semua terkumpul dan dapat diolah oleh Biro Penjaminan Mutu (Universitas Sangga Buana, 2015).

\subsection{Konsep Sistem Informasi Evaluasi Sistem Yang Sedang Berjalan}

Setelah melewati tahapan analisis terhadap prosedur sistem EDOM yang sedang berjalan Universitas Sangga Buana, maka dapat diketahui kelemahan-kelemahan yang terjadi yang disajikan dalam tabel berikut ini : 
Tabel 1. Kelemahan Sistem yang Berjalan

\begin{tabular}{|c|l|l|l|l|}
\hline No. & \multicolumn{1}{|c|}{ Objek } & \multicolumn{1}{|c|}{ Faktor } & \multicolumn{1}{|c|}{ Masalah } & \multicolumn{1}{c|}{ Solusi } \\
\hline 1 & Kuesioner & $\begin{array}{l}\text { Kuesioner } \\
\text { masih berupa } \\
\text { kertas }\end{array}$ & $\begin{array}{l}\text { Kemungkinan tidak } \\
\text { terisinya data oleh } \\
\text { mahasiswa, } \\
\text { kuesioner hilang. }\end{array}$ & $\begin{array}{l}\text { Dibuatkanya aplikasi yang } \\
\text { dapat menyimpan data } \\
\text { kedalam suatu database } \\
\text { yang terintegrasi sehingga } \\
\text { data aman dan mudah untuk } \\
\text { dicari ketika dibutuhkan }\end{array}$ \\
\hline 2 & $\begin{array}{l}\text { Rekap dan } \\
\text { Perhitungan } \\
\text { hasil } \\
\text { kuesioner }\end{array}$ & $\begin{array}{l}\text { Masih dengan } \\
\text { cara } \\
\text { konvensional }\end{array}$ & $\begin{array}{l}\text { Kemungkinan salah } \\
\text { input dan rekap } \\
\text { data, sehingga tidak } \\
\text { akuratnya informasi } \\
\text { yang di laporkan }\end{array}$ & $\begin{array}{l}\text { Dibuatnya aplikasi yang } \\
\text { dapat melakukan rekap data } \\
\text { secara otomatis dan } \\
\text { tersimpan dalam database } \\
\text { sehingga informasi menjadi } \\
\text { akurat }\end{array}$ \\
\hline
\end{tabular}

\subsection{Analisis Kebutuhan Sistem}

Setelah mendapatkan evaluasi pada sistem yang sedang berjalan maka kebutuhan sistem kedepannya adalah membuat sebuah aplikasi sistem informasi yang terintegrasi dengan website akademik USB YPKP yaitu sia.usbypkp.ac.id dengan membuat pola prosedur yaitu mahasiswa menginput data EDOM sebelum melihat dan mencetak Kartu Hasil Studi (KHS), jika mahasiswa tidak menginput data EDOM maka Mahasiswa tidak dapat melihat atau mencetak KHS dengan waktu yang telah ditentukan Universitas. Sehingga data EDOM yang semula kemungkinan ada mahasiswa yang tidak mengisi kuesioner, maka dengan adanya aplikasi sistem EDOM mahasiswa dipaksa untuk mengisi dan data yang dihasilkan akan maksimal. Lalu pada sisi dosen, dosen dapat melihat langsung hasil EDOM dengan sendiri dengan mengakses sia.usbypkp.ac.id yang telah diintegrasikan dengan aplikasi sistem EDOM. Berikutnya pada sisi petugas, petugas tidak kewalahan dengan rekap data laporan yang mungkin kertas kuesioner hilang atau tidak terarsip dengan benar, lalu untuk perhitungan yang kemungkinan salah atau tidak akurat, dengan adanya aplikasi sistem EDOM yang baru perhitungan sudah secara otomatis terhitung dan tersimpan pada database sehingga keakuratan dapat terjamin.

\subsection{Use Case Diagram}

Berikut ini adalah use case diagram perancangan sistem yang diusulkan dapat dilihat pada gambar 2. 
Analisis dan Perancangan Sistem Informasi Evaluasi Dosen Oleh Mahasiswa di Lingkungan Universitas Sangga Buana Bandung

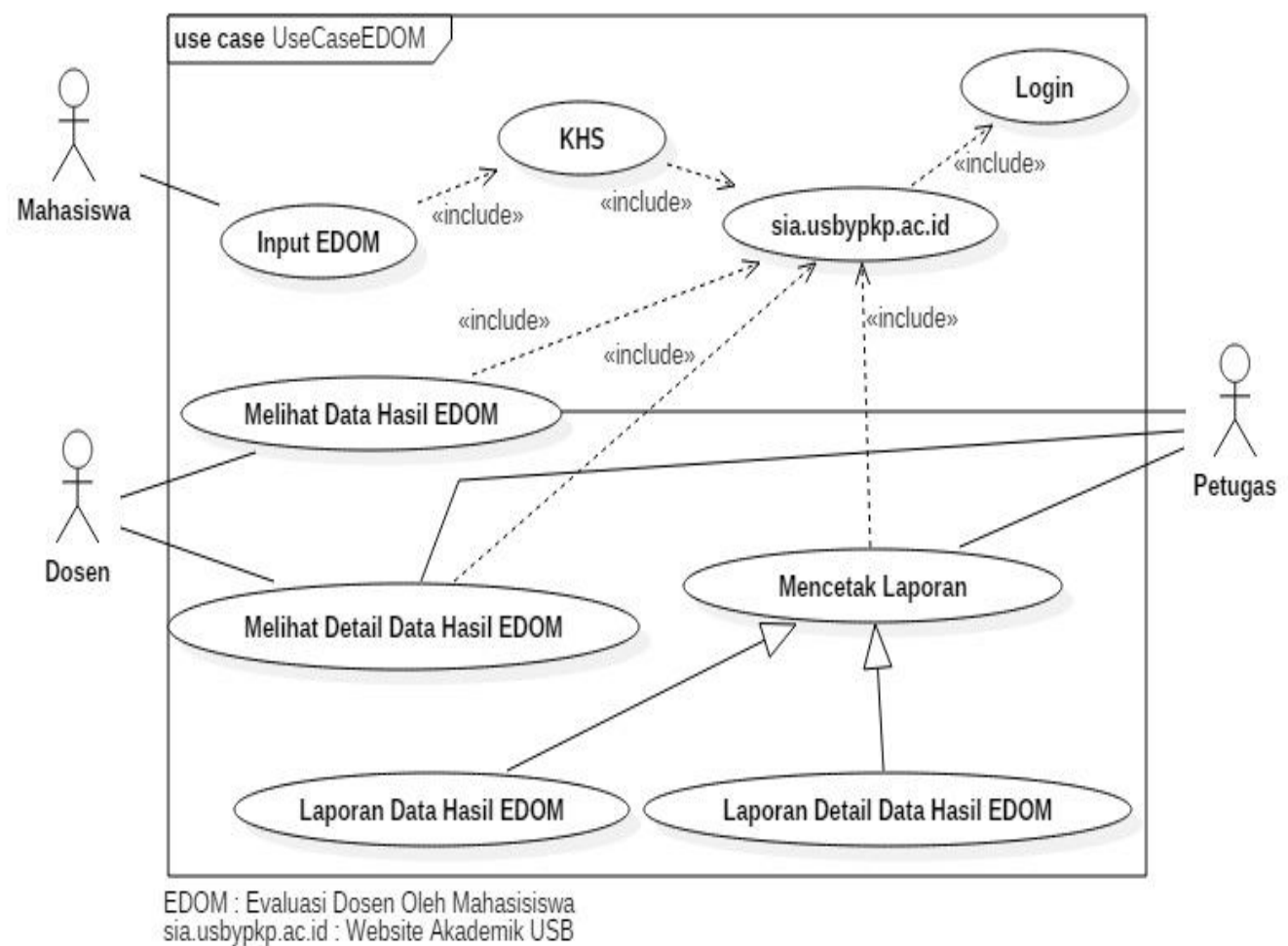

Gambar 2. Use Case Diagram Sistem Yang Diusulkan

\subsection{Activity Diagram}

Berikut ini adalah Activity diagram perancangan sistem yang diusulkan dapat dilihat pada gambar 3 sampai dengan 7.

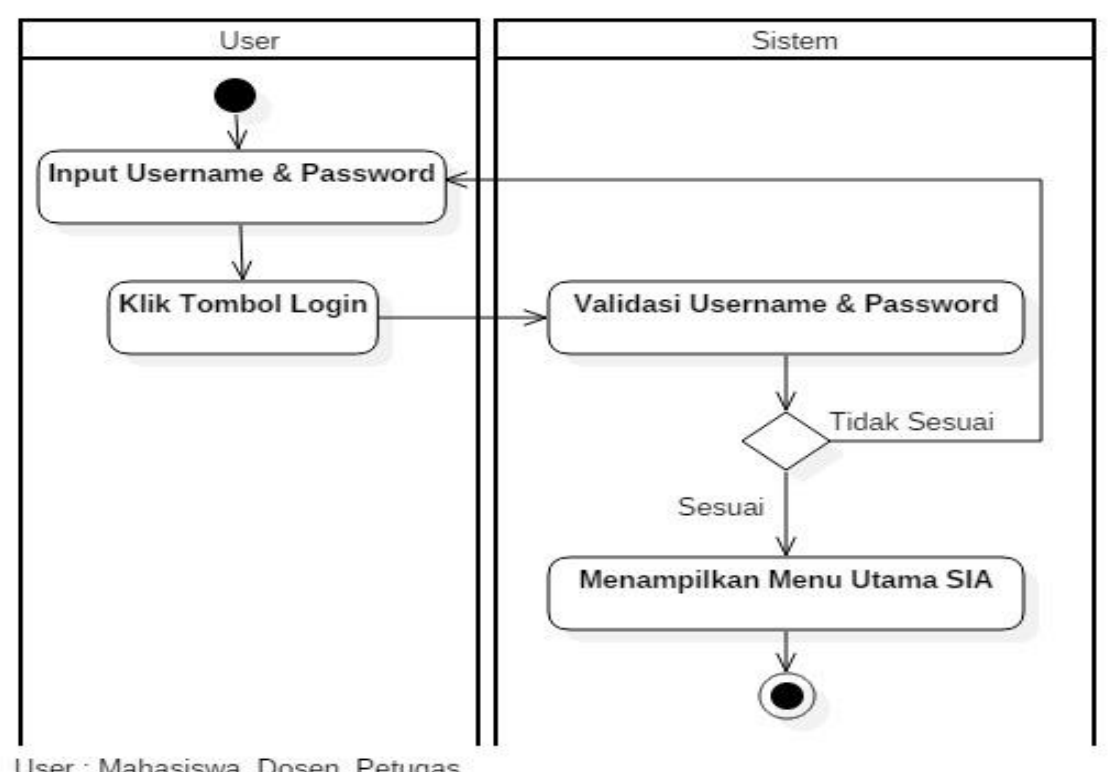

Gambar 3. Activity Diagram Login 


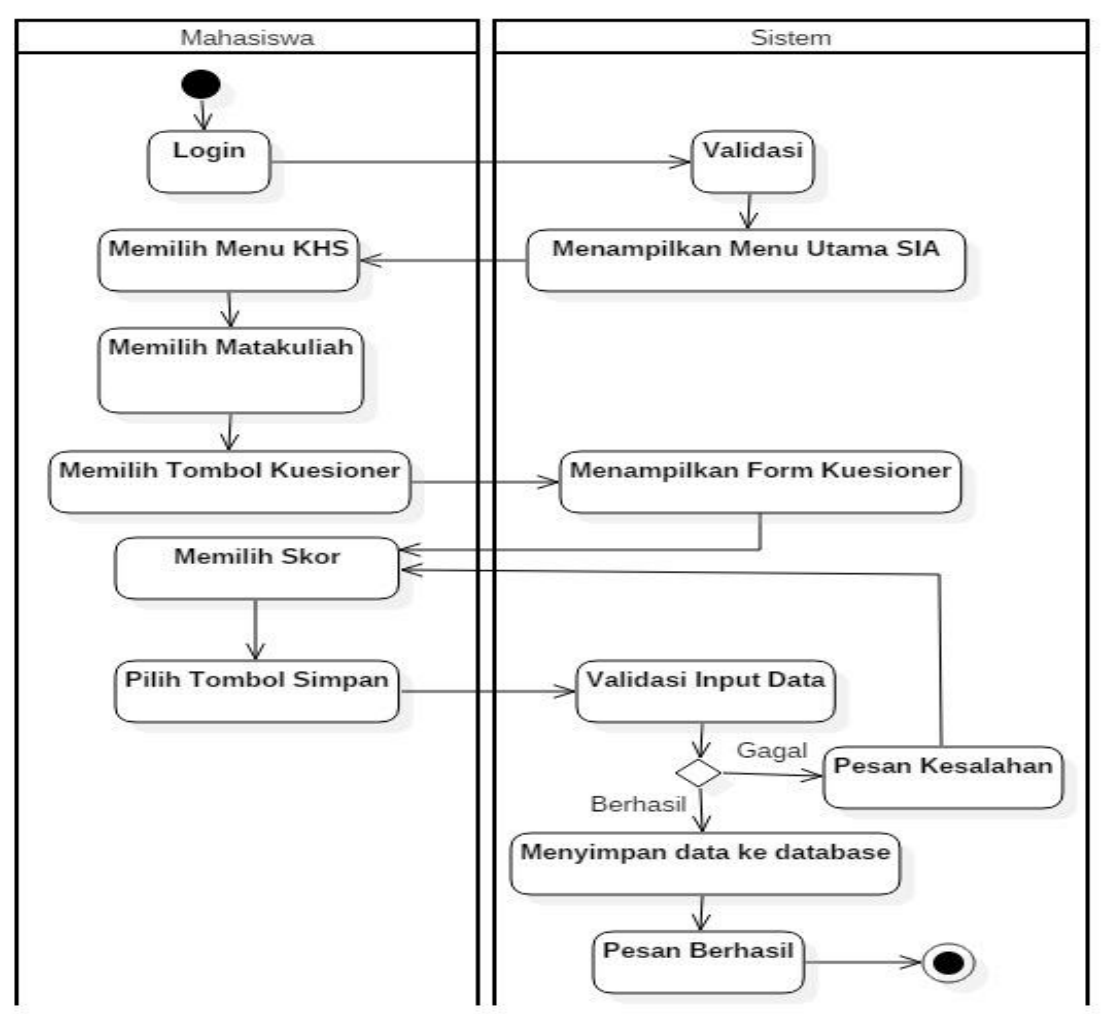

Gambar 4. Activity Diagram Input Data EDOM

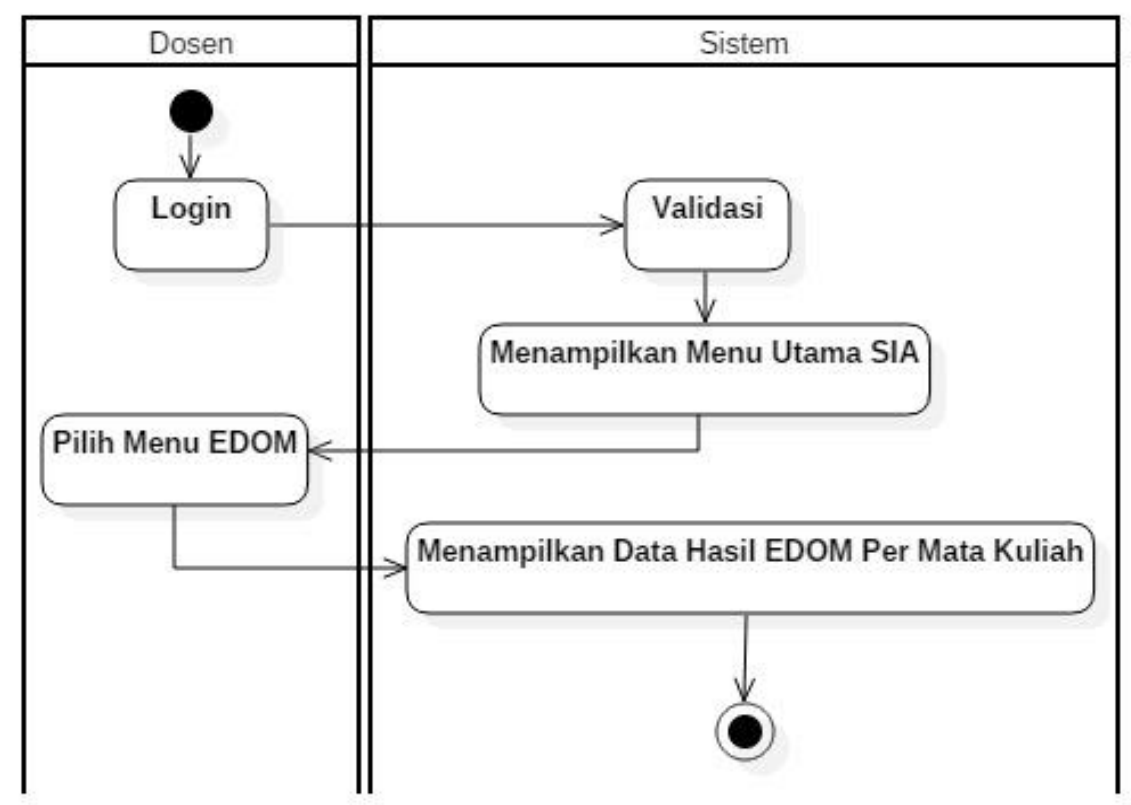

Gambar 5. Activity Diagram Dosen Melihat Data Hasil EDOM 
Analisis dan Perancangan Sistem Informasi Evaluasi Dosen Oleh Mahasiswa di Lingkungan Universitas Sangga Buana Bandung

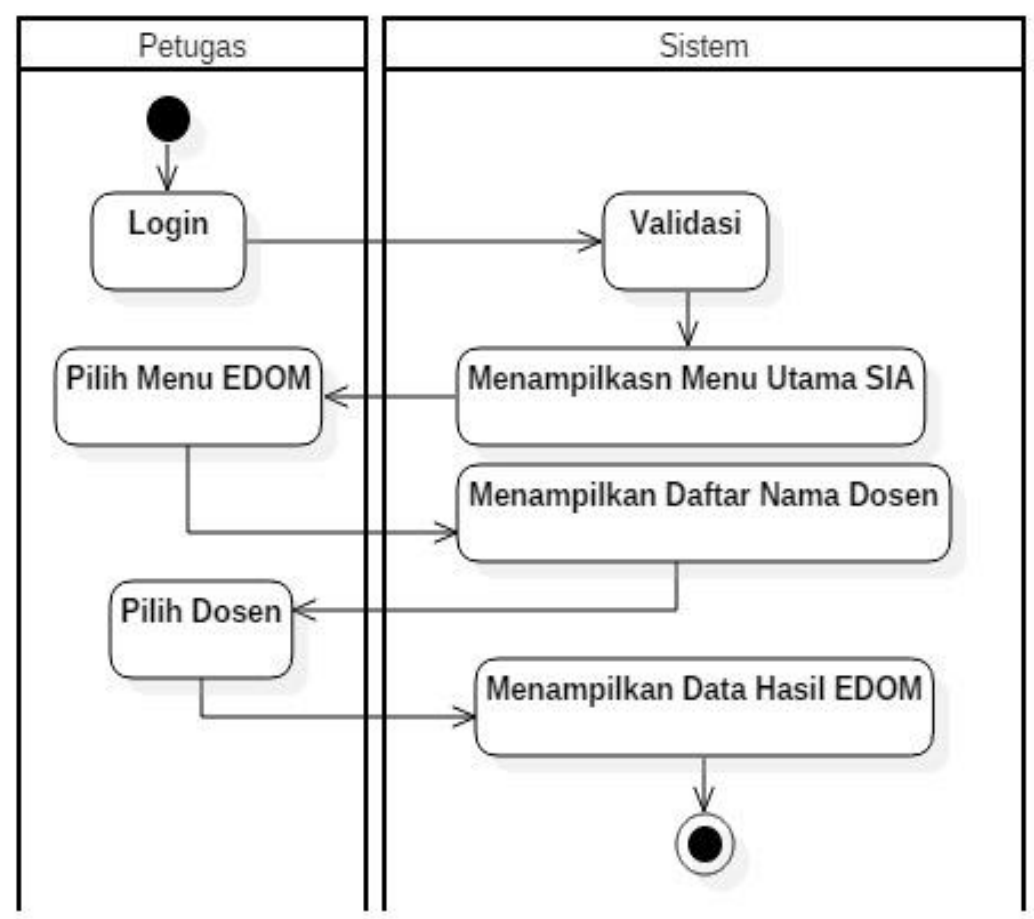

Gambar 6. Activity Diagram Petugas Melihat Data Hasil EDOM

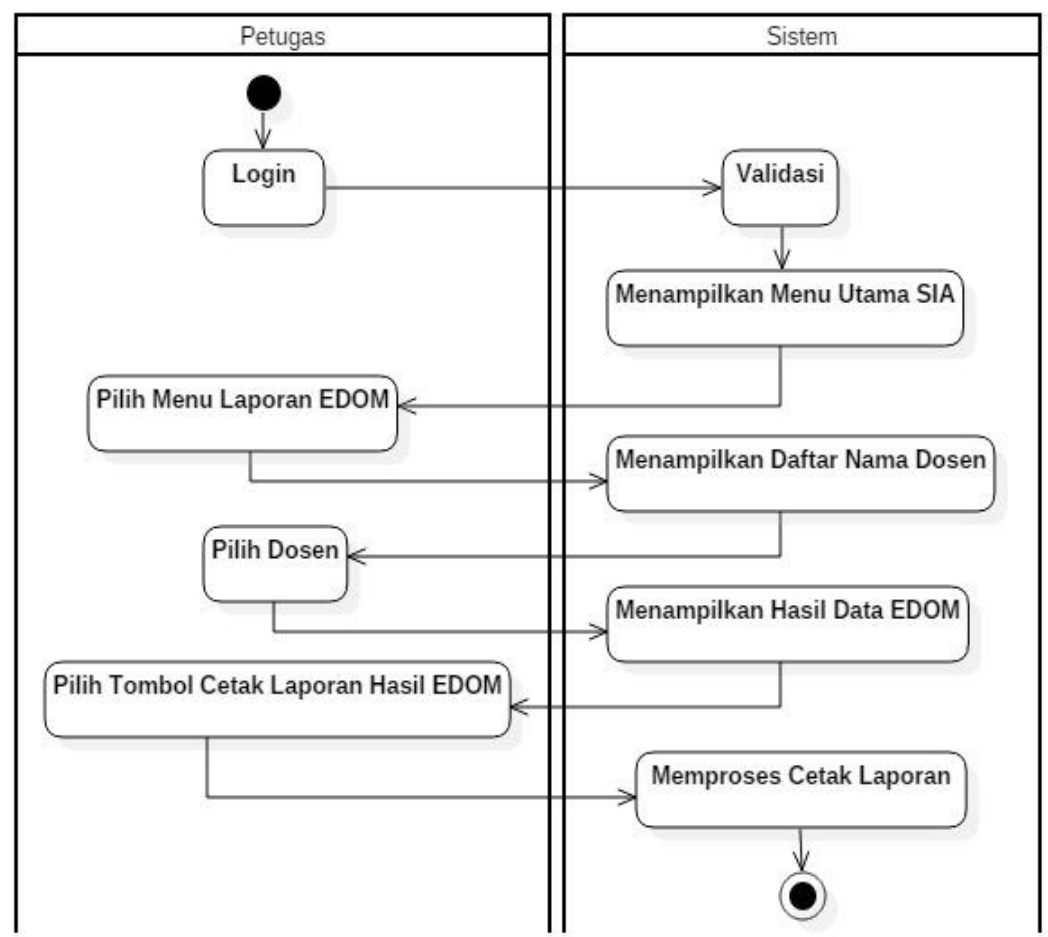

Gambar 7. Activity Diagram Petugas Mencetak

Laporan Data Hasil EDOM 


\subsection{Entity Relationship Diagram}

Berikut ini adalah entity relationship diagram perancangan relasi data pada sistem yang diusulkan dapat dilihat pada gambar 8.

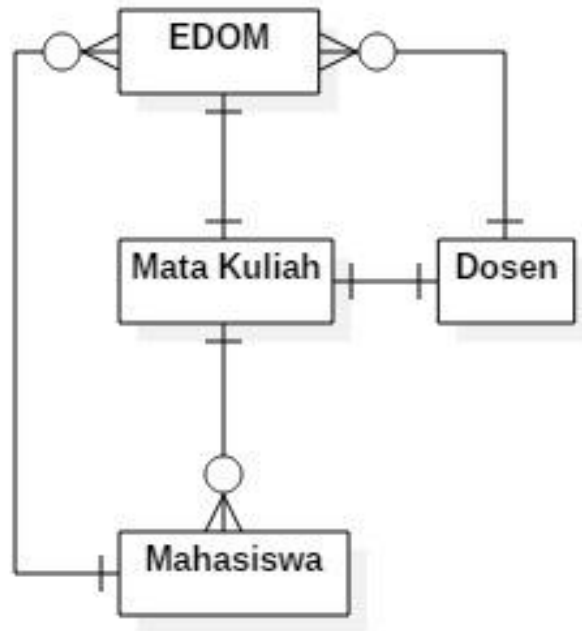

\section{Gambar 8. Entity Relationship Diagram EDOM}

\subsection{Perancangan User Interface}

Berikut ini adalah rancangan user interface untuk sistem yang diusulkan dapat dilihat pada gambar 9 sampai dengan 13.

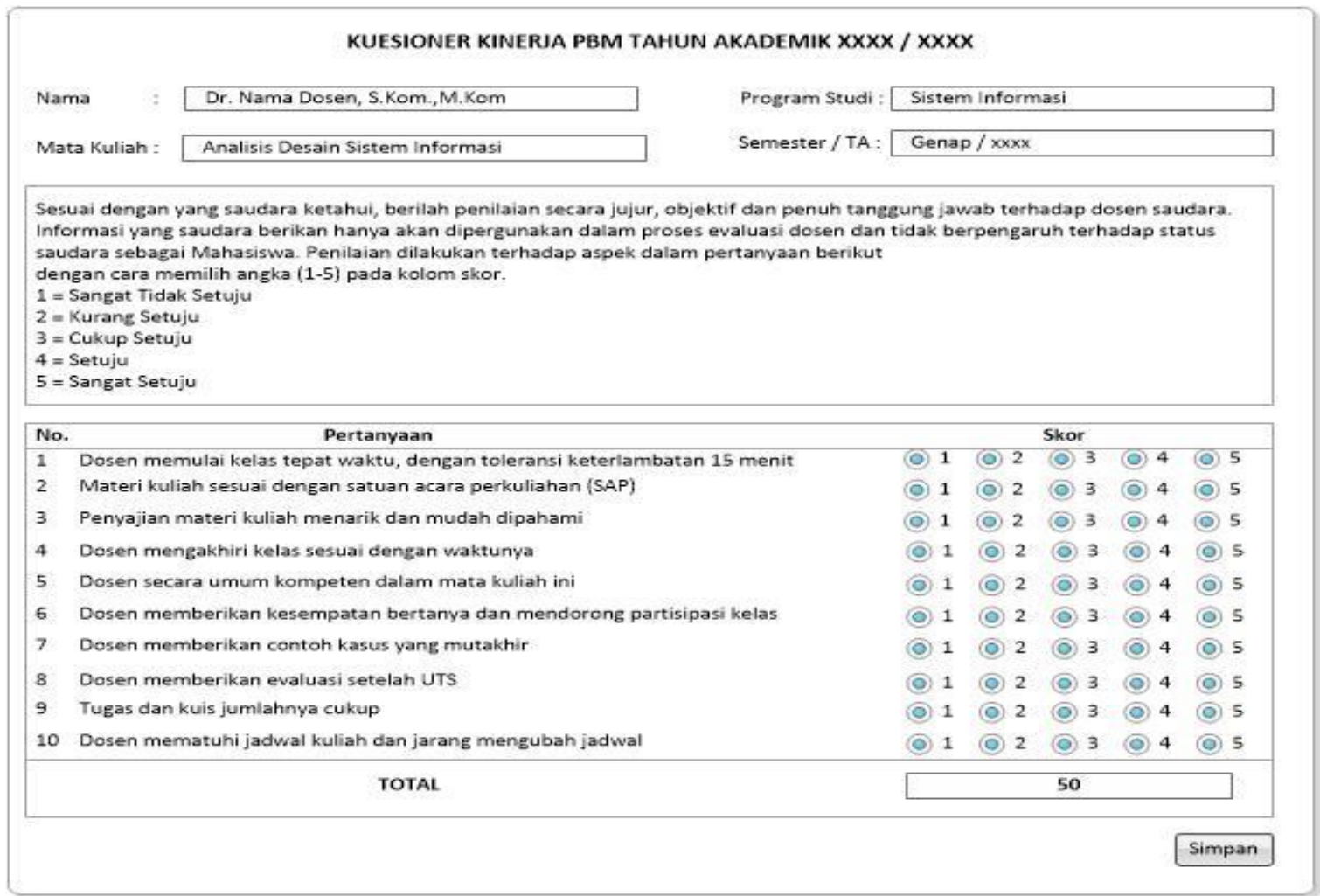

\section{Gambar 9. Tampilan Input Data EDOM}


Analisis dan Perancangan Sistem Informasi Evaluasi Dosen Oleh Mahasiswa di Lingkungan Universitas Sangga Buana Bandung

\begin{tabular}{|c|c|c|c|c|c|c|}
\hline \multicolumn{7}{|c|}{ HASIL EVALUASI DOSEN OLEH MAHASISWA TAHUN AKADEMIK $x x x x / x x x x$} \\
\hline Nam: & : & Dr. Nama Dosen, S.Kom.,M.Kom & Program & i : Sis: & ormasi & \\
\hline No. & Kode & Nama Mata Kuliah & Program Studi & Total & Kesimpulan & Aksi \\
\hline 1 & SSI206 & Analisis Desain Sistem Informasi & Sistem Informasi & 50 & Sangat Baik & Detail \\
\hline 2 & SSI207 & Praktek Pemrograman Website & Sistem Informasi & 40 & Baik & Detail \\
\hline
\end{tabular}

Gambar 10. Tampilan Untuk Dosen

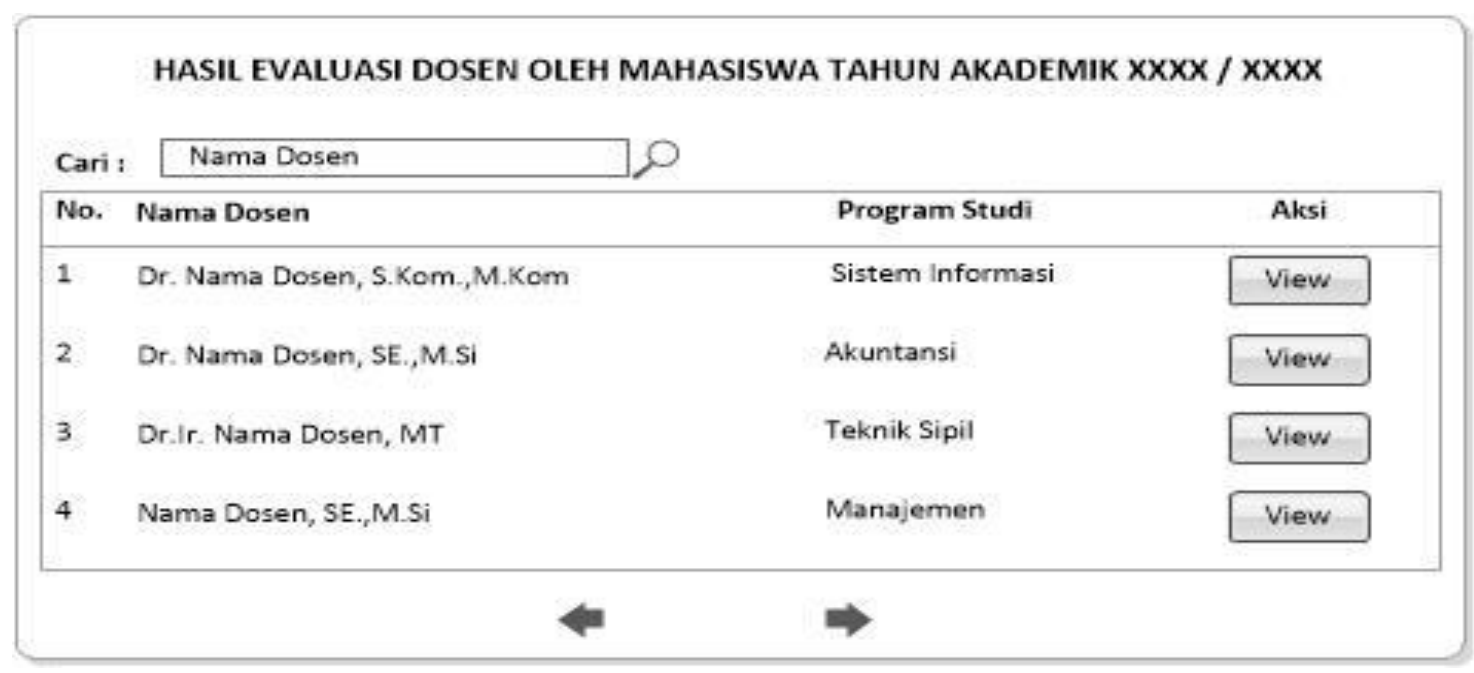

\section{Gambar 11. Tampilan Daftar Nama Dosen Untuk Petugas}

\begin{tabular}{|c|c|c|c|c|c|c|c|}
\hline \multicolumn{8}{|c|}{ HASIL EVALUASI DOSEN OLEH MAHASISWA TAHUN AKADEMIK XXXXX / XXXXX } \\
\hline \multicolumn{2}{|c|}{ Nama } & Dr. Nama Dosen, S.Kom.,M.Kom & \multicolumn{2}{|c|}{ Program Studi : } & Sistem Informasi & & \\
\hline No. & Kode & Nama Mata Kuliah & Program Studi & Total & Kesimpulan & & Aksi \\
\hline 1 & SSI206 & Analisis Desain Sistem informasi & Sistem informasi & 50 & Sangat Baik & Detail & Cetak \\
\hline 2 & $\$ S 1207$ & Praktek Pemrograman Website & Sistem Informasi & 40 & Baik & Detail & Cetak \\
\hline
\end{tabular}

\section{Gambar 12. Tampilan Hasil EDOM Dosen Untuk Petugas}




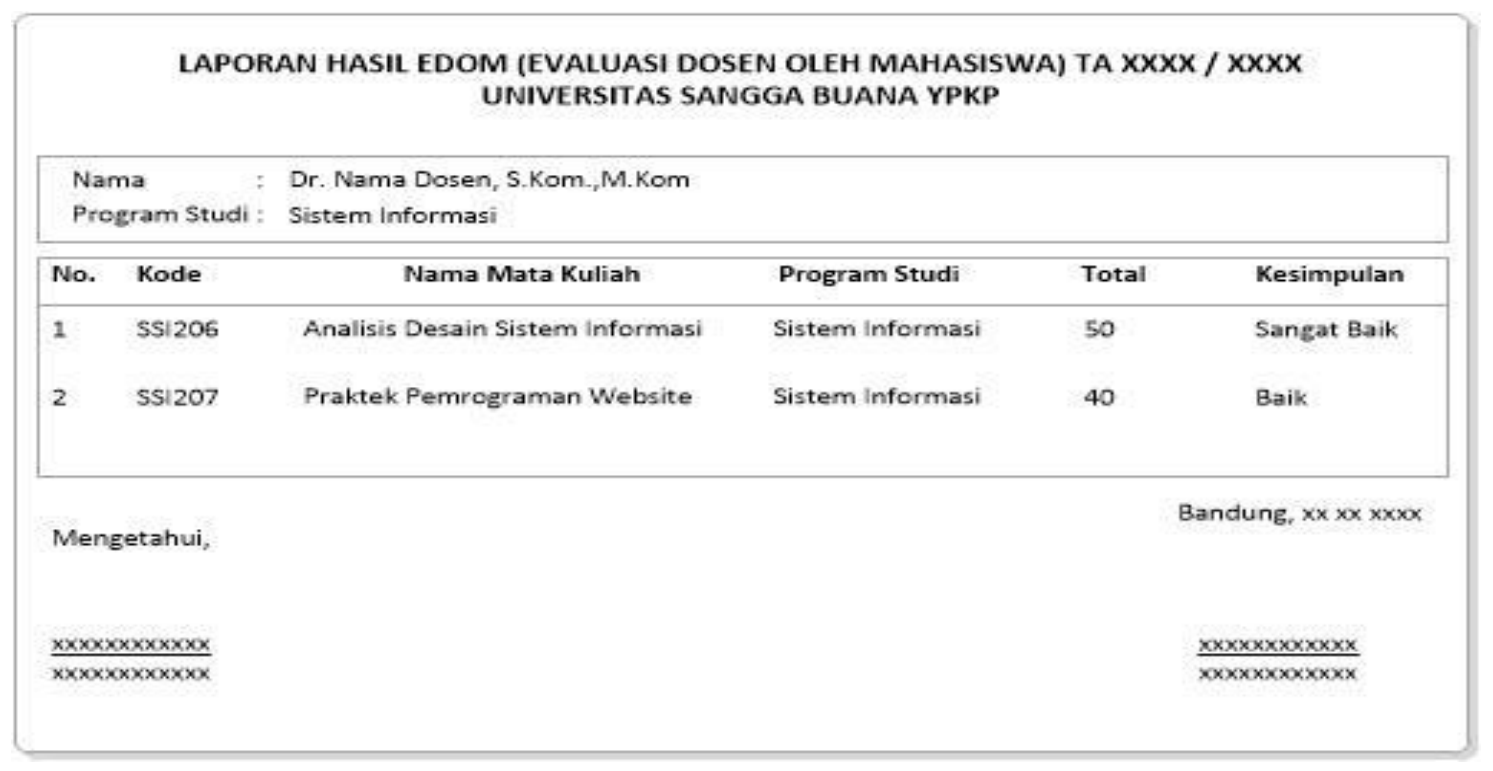

Gambar 13. Tampilan Laporan Hasil EDOM

\section{KESIMPULAN}

Dari analisis dan perancangan yang dilakukan pada penelitian ini telah menghasilkan blueprint, dimana blueprint tersebut dapat menjabarkan kebutuhan yang mengenai aplikasi sistem informasi EDOM yang diterapkan bersamaan dengan sistem informasi yang telah ada sebelumnya.

\section{DAFTAR RUJUKAN}

Irawan. (2017). Pengembangan Sistem Informasi Evaluasi Dosen Oleh Mahasiswa (EDOM) Pada STIKOM Dinamika Bangsa Jambi, JURNAL ILMIAH MEDIA SISFO, 11(2), 938 953.

Jogiyanto. (2005). Analisis Dan Desain Sistem Informasi : Pendekatan Terstruktur, Teori Dan Praktik Aplikasi Bisnis. Yogyakarta: Andi.

J, Simarmata. (2007). Perancangan Basis Data. Yogyakarta: Andi.

Ladjamudin, Al-Bahra Bin. (2005). Analisis Dan Desain Sistem Informasi. Yogyakarta: Graha Ilmu.

Republik Indonesia. (2005). Undang-Undang Republik Indonesia Nomor 14 Tahun 2005 Tentang Guru dan Dosen. Sekretariat Negara. Jakarta.

Republik Indonesia. (2005). Undang-Undang Republik Indonesia Nomor 12 Tahun 2012 Tentang Pendidikan Tinggi. Jakarta.

Pressman, R. S. (2002). Rekayasa Perangkat Lunak. Yogyakarta: Andi.

Silberschatz, A., \& H. F. Korth. (2002). Database System Concept, 4 ed. The McGraw-Hill Companies, Inc. 
Analisis dan Perancangan Sistem Informasi Evaluasi Dosen Oleh Mahasiswa di Lingkungan Universitas Sangga Buana Bandung

Sunoto, A. (2018). Analisis dan Desain Sistem Informasi Penilaian Kinerja Dosen Berdasarkan Pelaksanaan Tridharma Perguruan Tinggi (Studi Kasus STIKOM Dinamika Bangsa Jambi), JURNAL ILMIAH MEDIA SISFO, 12(1), 966 - 985.

Universitas Sangga Buana. (2015). Daftar Prosedur Mutu Kegiatan Teknis Universitas Sangga Buana YPKP Bandung. Bandung.

Widodo, P. P., \& Herlawati. (2011). Menggunakan UML - UML Secara Luas Digunakan untuk Memodelkan Analisis \& Desain Sistem Berorientasi Objek. Bandung: Informatika. 